\title{
SUPERIMPOSED DRUMLINS
}

\author{
By J. Rose and J. M. Letzer \\ (Department of Geography, Birkbeck College, University of London, London WIA IPA, \\ England)
}

\begin{abstract}
Drumlins in parts of central Scotland and east Cumbria form two populations according to their size. In certain cases the small features are superimposed on the large. Drumlins, superimposed drumlins, and megadrumlins are considered to be part of a continuum of glacier bed forms, which is the product of changes in the stress applied by glaciers and the strength of bed material. Glacier behaviour can be inferred on the basis of this interpretation.

Résumé. Drumlins de surimposition. Les drumlins dans une partie de l'Écosse Centrale et de l'Est de Combres forment deux populations selon leurs dimensions. Dans certains cas, de petites formations sont superposées à des plus grandes. Les drumlins, drumlins de surimposition et megadrumlins, sont considérés comme une partie d'une gamme continue de formes propres aux lits glaciaires qui résulte de changements dans les contraintes appliquées par les glaciers et dans la résistance des matériaux du lit. On peut, sur la base de cette interprétation, reconstituer le comportement du glacier.

Zusammenfassung. Aufgesetzte Drumlins. Drumlins in Teilen von Mittel-Schottland und Cumbrien bilden zwei grössenabhängige Scharen. In bestimmten Fällen sind die kleineren Formen den grossen aufgesetzt. Drumlins, aufgesetzte Drumlins und Grossdrumlins werden als Teil eines Kontinuums von Formen am Gletscheruntergrund betrachtet, das das Ergebnis von Schwankungen der vom Gletscher aufgeprägten Spannung und der Festigkeit des Untergrundmaterials ist. Auf der Grundlage dieser Interpretation kann auf das Gletscherverhalten geschlossen werden.
\end{abstract}

\section{INTRODUGTION}

In the process of mapping glacial landforms around Glasgow and Kirkby Stephen it became apparent that the drumlins in certain areas formed two groups which could be distinguished on the basis of size, and that some small low-relief drumlins were superimposed on the large drumlins of high relief. Similar forms and relationships have been noted during detailed geomorphological mapping around Gargrave in West Yorkshire, Wigtown in south-west Scotland (personal communication from G. Wallace) and Carlisle in north Cumbria (personal communication from J. Boardman). "Superimposed" drumlins had earlier been observed by Fairchild (1929) in New York State, U.S.A., and "small drumlins plastered on the side of larger ones" were recorded by Hollingworth (193 I, p. 326) in Cumbria, England. However, traditionally drumlins have been considered as part of a unimodal population which may or may not vary across an area (Embleton and King, 1975). This paper presents evidence that more than one size population may exist in a given area and examines the significance of this property.

\section{LOGATION OF SAMPLE AREAS}

The samples on which this study is based are taken from parts of the Glasgow and Vale of Eden drumlin fields (Fig. I), which have been mapped at a scale of 1 : ro 560 (Rose and Letzer, 1975). In the Glasgow area, the drumlins are orientated west-east across central Scotland, except around the southern margin of Loch Lomond where they form a fan-like pattern with a predominantly north-south trend. In eastern Cumbria, the drumlins converge on Stainmore from the north-west, west, and south-west, except in the western part where they trend north-south. In both areas the drumlins were formed during the Devensian glaciation. Around Loch Lomond they can be specifically related to the Late-glacial re-advance of Younger Dryas age. 


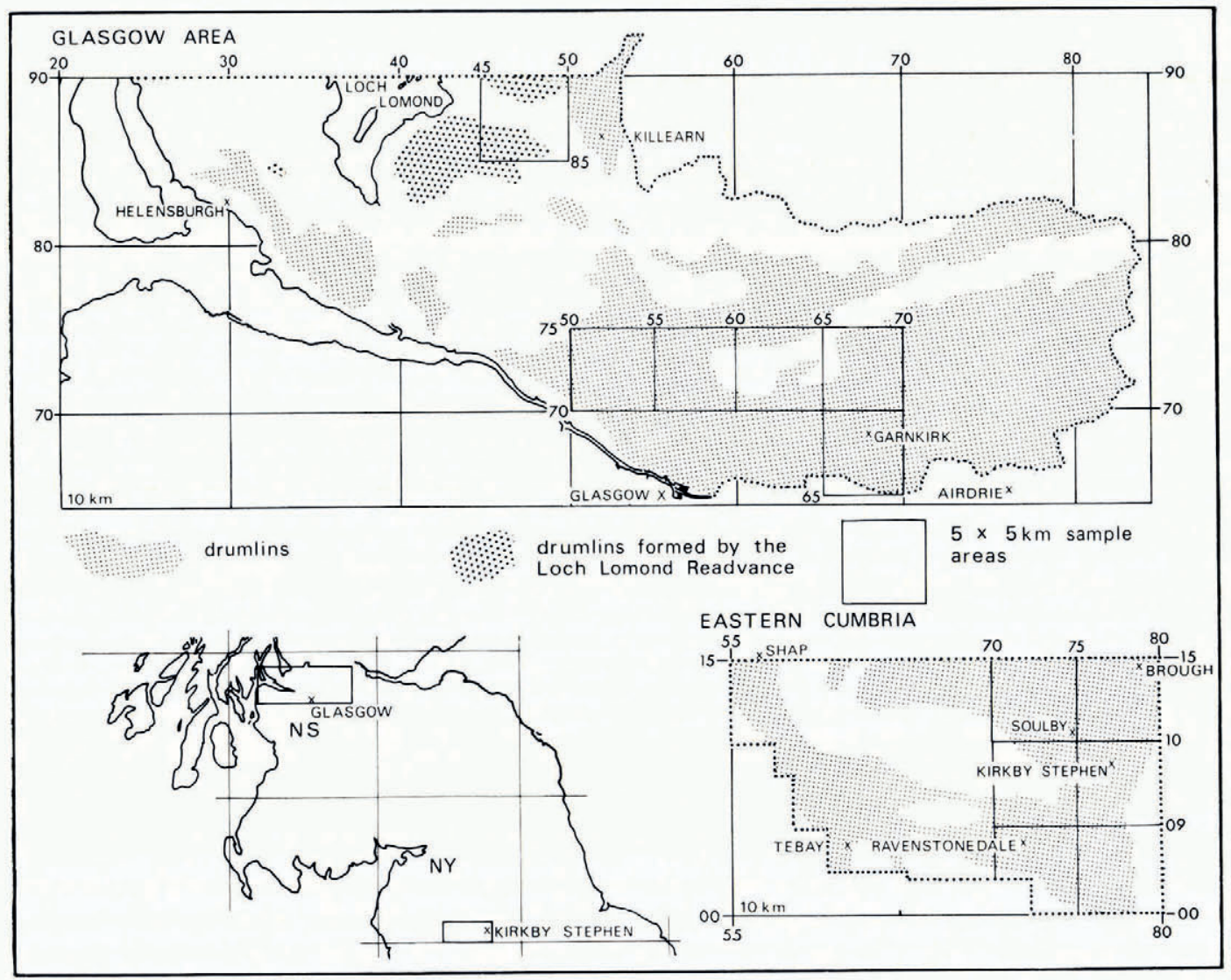

Fig. I. Location of drumlin fields and sample areas.

\section{FieLd OBSERVATIONS AND DEFINITIONS}

In parts of both drumlin fields, such as the areas around Loch Lomond in the Glasgow area, and around Shap, Ravenstonedale, and Kirkby Stephen in eastern Cumbria, the drumlins appear to fall within a single size range. In other parts of the areas, however, such as most of the Glasgow area between Helensburgh and Airdrie, and the Brough area of eastern Cumbria, the drumlin landscape consists of a large number of small drumlins and occasional, conspicuous large drumlins (Fig. 2). In these areas also, many small drumlins appear to have been formed on the surfaces of landforms which have the shape and dimensions of the large drumlins. The impression is obtained that the small drumlins are superimposed on larger ones and this is substantiated by the maps (Figs 3 and 4 ).

For present purposes, the term drumlin is used for small features, whereas megadrumlin is applied to the large features by analogy with ripples and megaripples (see discussion, p. 477). Drumlins formed on the surface of megadrumlins are called superimposed drumlins.

The ability to recognize drumlins, superimposed drumlins, and megadrumlins varies with the degree of modification of the megadrumlin and the differences in the orientation of the crest lines of the large and small features. For instance, at the simple level, megadrumlins may be unmodified (large drumlins; Fig. 2) or only partially modified by superimposed drumlins (Fig. 3), in which case one or two drumlins usually cover the side or distal part of 
the megadrumlin (Fig. $3 \mathrm{a}-\mathrm{c}$ ). Occasionally the drumlins may be located at the proximal end or even over the highest point on the crest line (Fig. $3 \mathrm{~d}-\mathrm{f})$. At the simple level, the whole or a large proportion of the megadrumlin outline remains and can be mapped in the field. Usually, also, the crest line and the highest point of the megadrumlin are recognizable in the field.

At the more complex level, superimposed drumlins may obscure the whole of the megadrumlin and the original feature can only be recognized by its plan and large-scale relief.

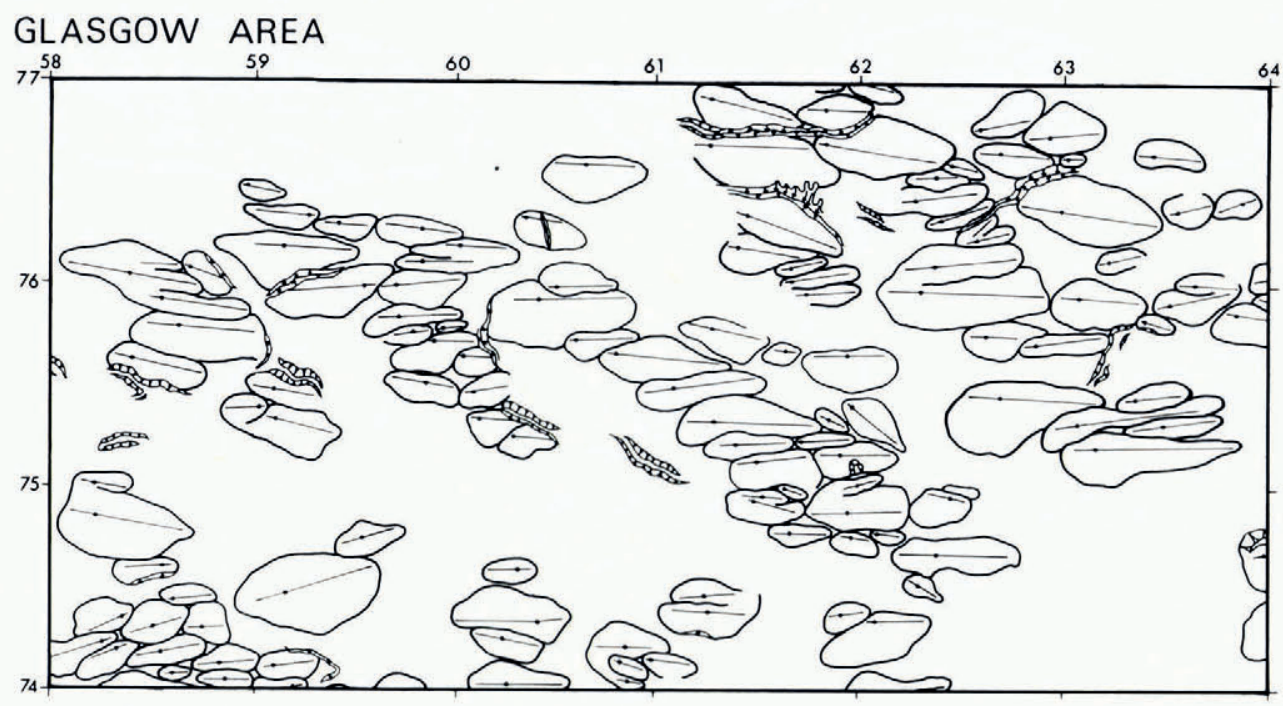

\section{EASTERN CUMBRIA}

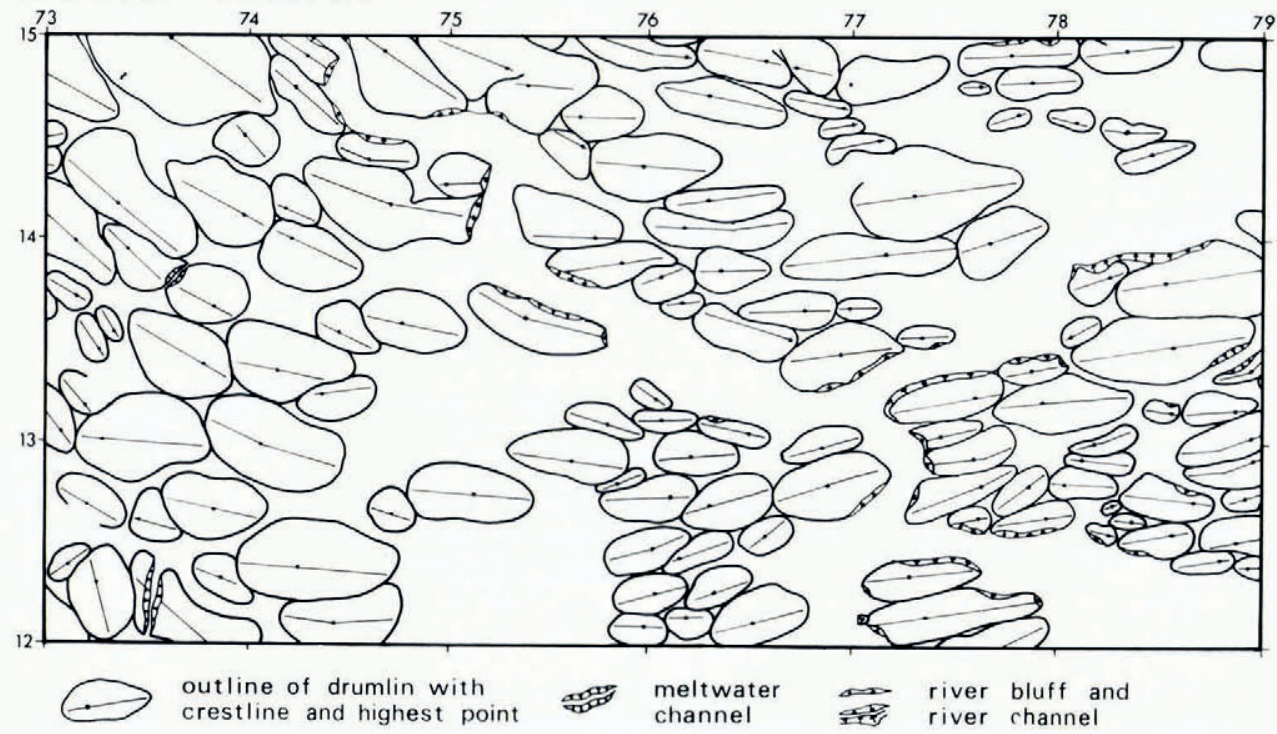

Fig. 2. An example of drumlins and megadrumlins from the Glasgow area and eastern Cumbria. The location of these map segments and their scale is indicated by the National Grid coordinates. 
In these cases a group of superimposed drumlins may cover the surface of the megadrumlin and clusters of up to nine superimposed drumlins have been distinguished (Fig. 4). The cluster pattern appears to vary with the relationship between the orientation of the drumlins and the orientation of the megadrumlin. Where the crest lines are roughly parallel, the highest drumlin is usually the largest and is located over the highest point of the megadrumlin. The smaller drumlins occur at successively lower elevations (Fig. $4^{\mathrm{a}}$ and d). Where the crest

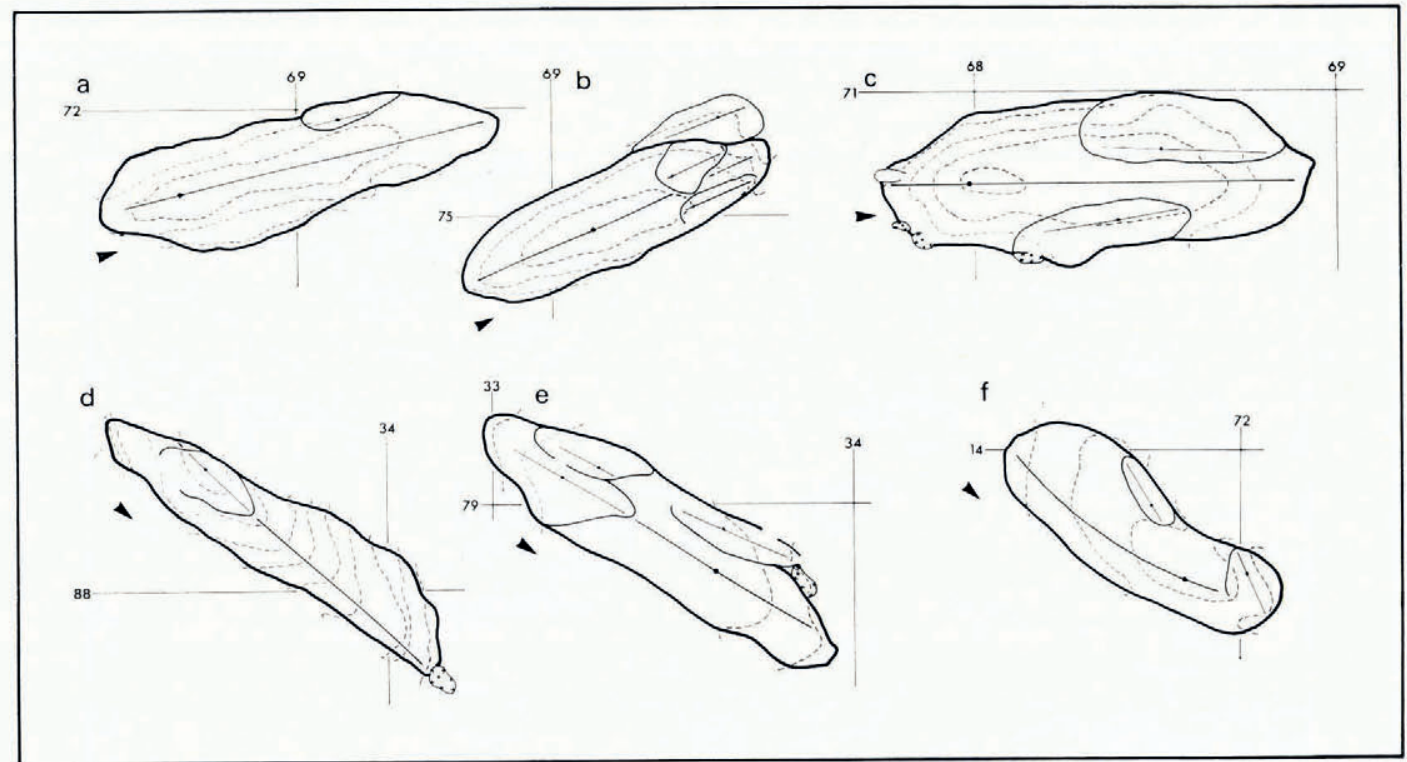

Fig. 3. Examples of simple superimposed drumlin-megadrumlin relationships In these cases large parts of the megadrumlins are unmodified, and the crest lines of the two sets of drumlins are parallel. The direction of ice movement is indicated by the arrow. a-e are from the Glasgow area, and $f$ is from eastern Cumbria. Contours are at $7.6 \mathrm{~m}$ intervals, and scale, location and orientation are indicated by National Grid lines.

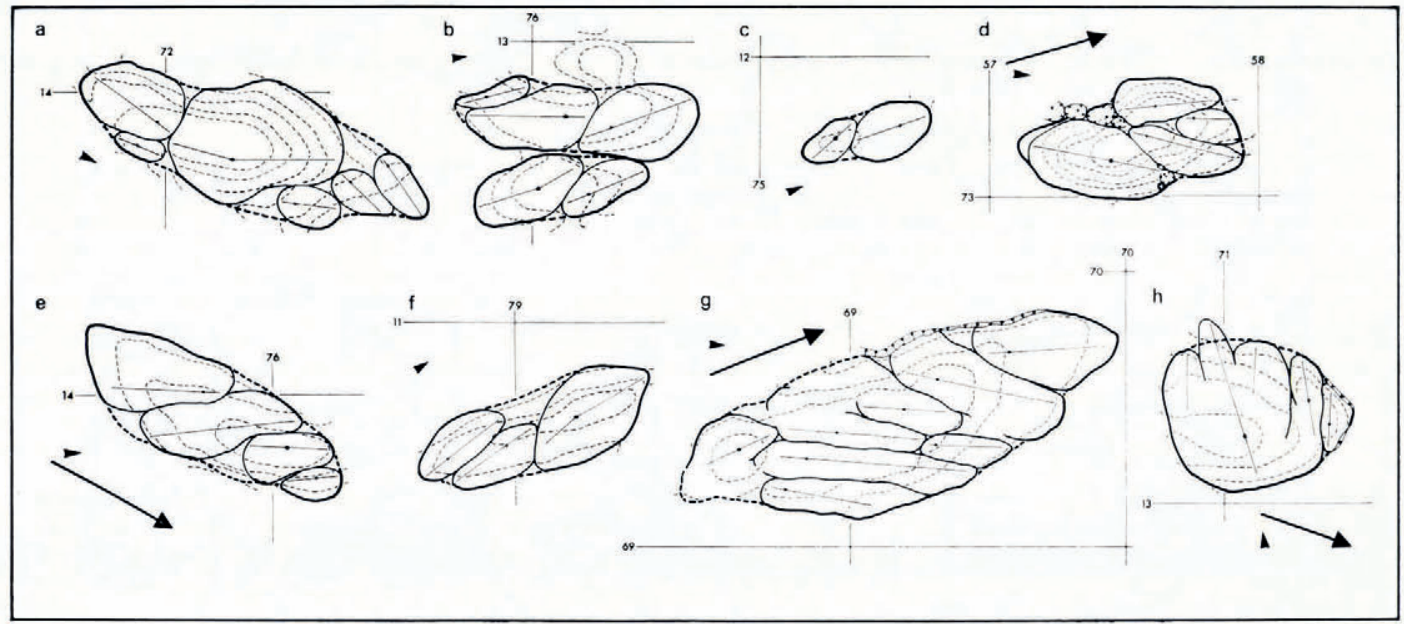

Fig. 4. Examples of complex superimposed drumlin-megadrumlin relationships. In examples a-c and $f$ the direction of ice movement associated with the formation of the megadrumlins and superimposed drumlins is similar. In cases $d, e, g$ and $h$ the directions are different and the interpreted directions associated with the formation of the megadrumlins are indicated by the large arrow. $a-c, e, f$ and $h$ are from eastern Cumbria and $d$ and $g$ are from the Glasgow district. Contours are at $7.6 \mathrm{~m}$ intervals, and scale, location and orientation are indicated by National Grid lines. 


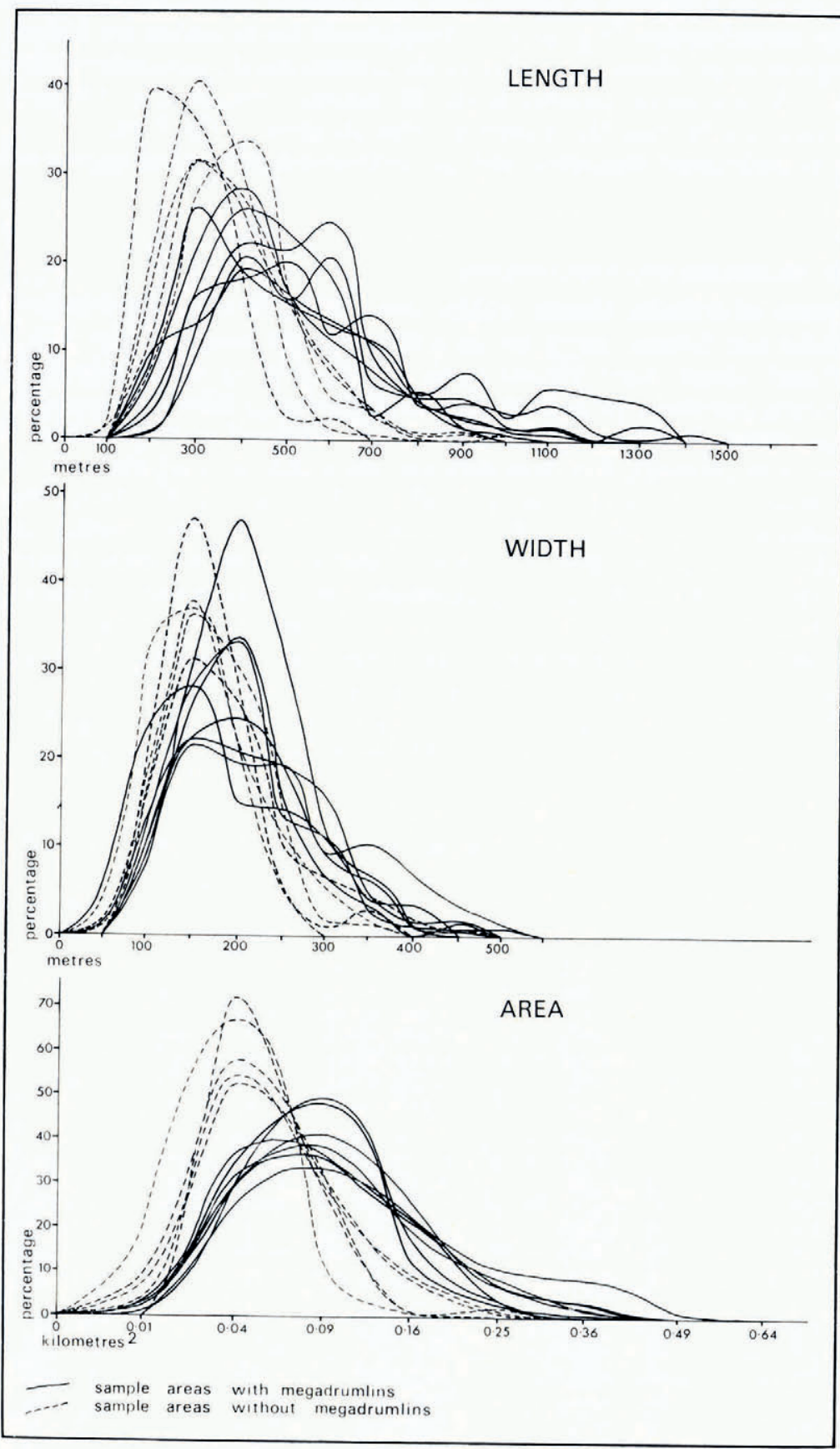

Fig. 5. Histograms of drumlin dimensions. These are taken from the sample areas indicated in Figure $I$ and are defined according to whether the sample areas contain megadrumlins and drumlins, or drumlins only. 
lines of the megadrumlin and drumlins have an oblique relationship, the drumlins are usually of similar size and are arranged en échelon with their highest points aligned roughly along the crest line of the megadrumlin (Fig. $4 \mathrm{e}-\mathrm{g}$ ). Occasionally the drumlins are formed on only one side of the megadrumlin, which then takes on an asymmetrical appearance with one irregular edge (Fig. 4h). At this more complex level, the outline, crest line, and highest point of the megadrumlin may not be capable of primary identification in the field.

Drumlins, superimposed drumlins, and unmodified megadrumlins appear to be randomly juxtaposed.

\section{Quantitative measurements and analysis}

Measurements of drumlin length, width, and area were abstracted from the I : io 560 field maps (Rose and Letzer, I975) for $125 \mathrm{~km}$ by $5 \mathrm{~km}$ sample areas (Fig. I). The size dimensions of each sample were plotted as histograms (Fig. 5) on the expectation that data taken from an area including megadrumlins would produce a bimodal frequency distribution with a primary mode of drumlins and a secondary mode of megadrumlins. However, all samples proved to be unimodal but those with megadrumlins were significantly more positively skewed than those without, and it was considered that the negative tails reflect the megadrumlin contribution. The absence of a trough between the two populations is explained either by a relatively large number of partially modified megadrumlins of intermediate size or by the fact that the drumlins and megadrumlins are part of a size continuum.

Since the drumlins and megadrumlins could not be separated on the histograms, further analysis concentrated on megadrumlins with overlying superimposed drumlins as these could be ascribed unequivocably to one or other of the groups. Mean values were determined for the samples and, although the results showed a wide range, the megadrumlins were at least $\mathrm{r} .7$ times as long, I.5 times as wide and 2.6 times the area of the superimposed drumlins (Table I).

Table I. Dimensions of Megadrumlins and OVERlying SUPERIMPOSED DRUMLins

\begin{tabular}{|c|c|c|c|c|c|c|}
\hline & $\begin{array}{l}\text { Coordinates of } \\
\text { sample area }\end{array}$ & $\begin{array}{c}\text { Mean } \\
\text { length } \\
\mathrm{km}\end{array}$ & $\begin{array}{c}\text { Mean } \\
\text { width } \\
\mathrm{km}\end{array}$ & $\begin{array}{c}\text { Mean } \\
\text { area } \\
\mathrm{km}^{2}\end{array}$ & $\begin{array}{c}\text { Mean } \\
\text { azimuth } \\
\text { deg }\end{array}$ & $\begin{array}{l}\text { Mean } \\
\text { E.R. }\end{array}$ \\
\hline Megadrumlins & $\begin{array}{l}\text { NS } 50-55,70-75 \\
\text { NS } 55^{-60}, 70-75 \\
\text { NS } 60-65,70-75 \\
\text { NS } 65^{-70,65-70} \\
\text { NS } 65^{-70,} 70-75 \\
\text { NY } 70-75, \text { 10-15 } \\
\text { NY } 75^{-80,} \text { 10-15 }\end{array}$ & $\begin{array}{l}0.825(0.060) \\
0.829(0.053) \\
0.671(0.049) \\
1.085(0.087) \\
1.193(0.046) \\
0.870(0.060) \\
0.900(0.058)\end{array}$ & $\begin{array}{l}0.319(0.017) \\
0.392(0.019) \\
0.286 \text { (o.019) } \\
0.408(0.037) \\
0.359(0.025) \\
0.385(0.024) \\
0.316(0.020)\end{array}$ & $\begin{array}{l}0.185(0.015) \\
0.221(0.029) \\
0.147(0.017) \\
0.337(0.049) \\
0.316(0.026) \\
0.268(0.029) \\
0.220(0.022)\end{array}$ & $\begin{array}{r}277.7(3.7) \\
257.7(3.7) \\
262.2(5.4) \\
258.0(3.0) \\
257.2(1.7) \\
107.9(3.5) \\
89.6(3.7)\end{array}$ & $\begin{array}{l}2.68(0.23) \\
2.14(0.12) \\
2.39(0.18) \\
2.73(0.15) \\
3.59(0.25) \\
2.30(0.13) \\
2.91(0.16)\end{array}$ \\
\hline $\begin{array}{l}\text { Superimposed } \\
\text { drumlins }\end{array}$ & $\begin{array}{l}\text { NS } 50-55,70-75 \\
\text { NS } 55-60,70-75 \\
\text { NS } 60-65,70-75 \\
\text { NS } 65-70,65-70 \\
\text { NS } 65-70,70-75 \\
\text { NY } 70-75,10-15 \\
\text { NY } 75-80,10-15\end{array}$ & $\begin{array}{l}0.4^{81}(0.047) \\
0.426(0.023) \\
0.3^{8} 3(0.034) \\
0.555(0.033) \\
0.695(0.050) \\
0.405(0.028) \\
0.423(0.021)\end{array}$ & $\begin{array}{l}0.156(0.013) \\
0.171(0.008) \\
0.163(0.020) \\
0.188(0.011) \\
0.217(0.014) \\
0.216(0.018) \\
0.208(0.012)\end{array}$ & $\begin{array}{l}0.065(0.010) \\
0.058(0.005) \\
0.054(0.010) \\
0.076(0.008) \\
0.122(0.015) \\
0.062(0.012) \\
0.069(0.007)\end{array}$ & $\begin{array}{r}270.9(1.7) \\
265.9(1.6) \\
269.2(2.4) \\
271.1(1.6) \\
258.9(1.3) \\
129.3(5.6) \\
78.3(2.6)\end{array}$ & $\begin{array}{l}3.01(0.16) \\
2.50(0.08) \\
2.60(0.22) \\
3.03(0.13) \\
3.27(0.17) \\
2.00(0.11) \\
2.08(0.07)\end{array}$ \\
\hline $\begin{array}{l}\text { Significance } \\
\text { level of } \\
\text { differences } \\
\text { between } \\
\text { mega- } \\
\text { drumlins } \\
\text { and }\end{array}$ & $\begin{array}{l}\text { NS } 50-55,70-75 \\
\text { NS } 55-60,70-75 \\
\text { NS } 60-65,70-75 \\
\text { NS } 65-70,65-70 \\
\text { NS } 65-70,70-75 \\
\text { NY } 70-75,10-15 \\
\text { NY } 75-80,10-15\end{array}$ & $\begin{array}{l}0.99[39] \\
0.99[69] \\
0.99[27] \\
0.99[64] \\
0.99[57] \\
0.99[47] \\
0.99[55]\end{array}$ & $\begin{array}{l}0.99[43] \\
0.99[69] \\
0.99[27] \\
0.99[63] \\
0.99[57] \\
o .99[44] \\
0.99[53]\end{array}$ & $\begin{array}{l}o .99[39] \\
0.99[69] \\
o .99[27] \\
o .99[6 \mathrm{I}] \\
0.99[56] \\
o .99[39] \\
0.99[53]\end{array}$ & $\begin{array}{c}\text { NS }[45] \\
\text { NS }[69] \\
\text { NS }[27] \\
\text { o.99 }[56] \\
\text { NS }[58] \\
\text { o.99 [47] } \\
\text { o.99 }[55]\end{array}$ & $\begin{array}{l}\text { NS }[39] \\
\text { NS [69] } \\
\text { NS }[27] \\
\text { NS [62] } \\
\text { NS [56] } \\
\text { NS [44] } \\
0.99[55]\end{array}$ \\
\hline
\end{tabular}
superimposed

drumlins

using

Student's

$t$ test

Figures in parentheses give the standard error of the mean. Figures in square brackets give degrees of freedom. 
Examination of the mean orientation and shape values indicates that in most of the areas sampled the superimposed drumlins and megadrumlins have a similar form. However, in the Soulby, Brough and Garnkirk areas, the crest-line trends are different, and in the Brough area the superimposed drumlins are less elongate (E.R.) than the underlying megadrumlins (Table I).

\section{Discussion}

Transport processes in many geomorphological systems produce equilibrium bed forms which develop a hierarchy of shapes in relation to available energy and sediment supply (Allen, I968). Thus, in river systems, bed forms change from plane beds through ripples, dunes (megaripples), plane beds and antidunes to bars (Leopold and others, 1964; Simons and others, I 965 ) ; in foreshore systems, sand beds change from plane beds through ripples and plane beds to megaripples (Clifton and others, 1971); and in aeolian systems, sand beds change from ripples through ribbons and dunes to draas (Wilson, 197I). In many cases the members of the hierarchy show a relationship between their size and the relative energy available. For instance, for a given sediment size, dunes are larger than ripples and draas are larger than dunes. In addition, the size of the individuals which make up each member of a hierarchy varies within the size range according to variations in available energy. Thus, dunes increase their dimensions with increase in water depth and bars increase their length with increases in river discharge.

It is suggested that drumlins and megadrumlins were formed similarly in response to variations in available energy and sediment supply at the ice-debris interface, and that they either form part of a bed-form hierarchy or part of a size continuum which ranges from fluted till found in currently or recently glacierized regions (Hoppe and Schytt, I953) to streamlined bedrock hills (Linton, 1962). Megadrumlins and drumlins are intermediate members of
either scheme.

The superimposition of the drumlins on the megadrumlins means that the two populations are related to a diminishing glacier energy regime. In this respect, they are analogous to dunes (megaripples) covered by ripples which are a typical effect of a decreasing aqueous flow regime. Diminishing energy conditions are, however, inherent for the preservation of more than one population of ice-moulded bed forms, as an increasing energy regime would either destroy the disequilibrated features or produce progressively larger forms which would bury and obscure the pre-existing features.

The formation of drumlins on megadrumlins can be explained in terms of the mechanism proposed by Smalley and Unwin (1968), if glacial deposits are re-worked during glaciation and subjected to progressive comminution. Under such circumstances, the stresses required to initiate deformation would diminish, so that at any given location drumlins or other glacial bed forms could be initiated by progressively thinner or slower-moving ice.

The character of the bed-form hierarchy will depend on changes in the shear strength of the bed material and in the stresses applied by the glacier ice (Fig. 6). Thus, if the shear strength of the bed material is relatively constant, equilibrium bed forms will develop with a single size range (Fig. 6(I)a). If, however, the shear strength of the bed material is reduced, an equivalent decrease in glacier energy will produce a hierarchy or continuum of equilibrium bed forms such as streamlined hills, through megadrumlins and drumlins to fluted moraine (Fig. 6(I)c). At a point in time these features will be distributed beneath the glacier with the smaller forms located close to the glacier margin and the larger forms located beneath the thicker ice. With a change of glacier stress through time, successive bed forms will be superimposed on pre-existing forms. Superimposed bed forms are most likely to be produced by an active back-wasting glacier which is continually re-working its bed material. 
HYPOTHETICAL CONDITIONS AT THE BASE OF A GLACIER LEADING TO THE FORMATION OF STREAMLINED BEDFORMS

KEY: $\quad$ glacier stress level — bed material resistance level

(1) Development of streamlined bedform assemblages when the glacier stresses and bed material resistance are in equilibrium

\begin{tabular}{|l|l|l|l|}
\hline Glacier state: & $\begin{array}{l}\text { Active ice, with constant } \\
\text { thickness and velocity }\end{array}$ & $\begin{array}{l}\text { Active ice, with increasing } \\
\text { thickness or velocity }\end{array}$ & $\begin{array}{l}\text { Active ice, with decreasing } \\
\text { thickness or velocity }\end{array}$ \\
\hline $\begin{array}{l}\text { Bed material } \\
\text { behaviour: }\end{array}$ & $\begin{array}{l}\text { No change } \\
\text { increased resistance due to } \\
\text { rock and improved packing }\end{array}$ & $\begin{array}{l}\text { Decreased resistance due to } \\
\text { comminution and looser } \\
\text { packing of bed material }\end{array}$ \\
\hline $\begin{array}{l}\text { Streamlined } \\
\text { bedforms: }\end{array}$ & $\begin{array}{l}\text { Single bedform } \\
\text { population }\end{array}$ & $\begin{array}{l}\text { Single population of large } \\
\text { bedforms produced during last } \\
\text { equilibrium stage }\end{array}$ & $\begin{array}{l}\text { Superimposed bedform } \\
\text { hierarchy of decreasing size }\end{array}$ \\
\hline
\end{tabular}

(2) Preservation of bedform assemblages when glacier stresses are insufficient to overcome bed material resistance
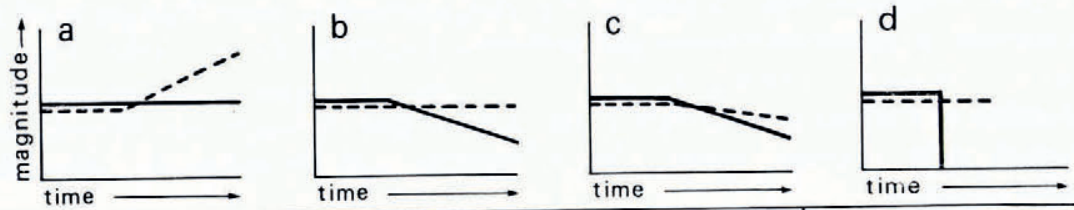

\begin{tabular}{|l|l|l|l|l|}
\hline Glacier state: & $\begin{array}{l}\text { Active ice, with constant } \\
\text { thickness or velocity }\end{array}$ & Active ice with decreasing thickness or velocity & Ice becomes stagnant \\
\hline $\begin{array}{l}\text { Bed material } \\
\text { behaviour: }\end{array}$ & $\begin{array}{l}\text { Increased resistance } \\
\text { due to fresh bedrock } \\
\text { incorporation and } \\
\text { improved packing }\end{array}$ & No change & $\begin{array}{l}\text { Decreased resistance } \\
\text { due to comminution \& } \\
\text { looser packing }\end{array}$ & Not applicable \\
\hline $\begin{array}{l}\text { Streamlined } \\
\text { bedforms: }\end{array}$ & Ice ineffective on bed material: fossil bedforms preserved & \\
\hline
\end{tabular}

(3) Cases in which equilibrium is re-established and two bedform populations are produced
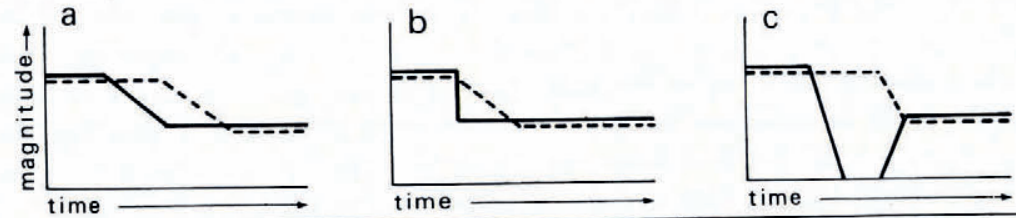

\begin{tabular}{|l|l|l|l|}
\hline Glacier state: & $\begin{array}{l}\text { Active ice, with a phase of } \\
\text { thinning or decreased velocity }\end{array}$ & $\begin{array}{l}\text { Stages of active ice separated } \\
\text { by stagnation }\end{array}$ & $\begin{array}{l}\text { Readvance, preceded by rapid } \\
\text { wastage }\end{array}$ \\
\hline $\begin{array}{l}\text { Bed material } \\
\text { behaviour: }\end{array}$ & $\begin{array}{l}\text { Resistance of bed material } \\
\text { becomes out of phase during } \\
\text { thinning }\end{array}$ & $\begin{array}{l}\text { Resistance decreases due to } \\
\text { increased pore water pressure } \\
\text { in bed material during } \\
\text { stag nation }\end{array}$ & $\begin{array}{l}\text { Resistance of upper part of bed } \\
\text { material reduced by } \\
\text { comminution during } \\
\text { re-advance }\end{array}$ \\
\hline $\begin{array}{l}\text { Streamlined } \\
\text { bedforms: }\end{array}$ & $\begin{array}{l}\text { Two populations of streamlined bedforms, a smaller magnitude set superimposed on pre-existing } \\
\text { larger forms }\end{array}$ \\
\hline
\end{tabular}

Note: Dilatancy may be increased by (a) fresh incorporation of bedrock and (b) improved packing of bed material. It may be decreased by (a) comminution and (b) looser packing of bed material

Fig. 6. Hypothetical conditions at the base of a glacier leading to the formation of streamlined bed forms. 
A terminated hierarchy is likely to be produced by a glacier which suffers a rapid decrease in stress caused by thinning or stagnation (Fig. 6(2)d). Finally, two separate bed-form populations are likely to be produced in an area where actively back-wasting ice is interrupted by a phase of thinning or decreased velocity (Fig. 6(3)a) or by stagnation (Fig. 6(3)b), or where stagnation is followed by a limited re-advance (Fig. 6(3)c).

Empirical support for this hypothesis is limited as quantitative analysis of glacier bed forms has been concerned predominantly with the relationship between glacier behaviour and bed-form shape (Chorley, I959; Trenhaile, I97 I; Embleton and King, 1975) rather than bed-form size. Such measurements as do exist are often unreliable (Rose and Letzer, 1975).

Near Carlisle in Cumbria, drumlins formed by a re-advance are recorded as smaller than those formed by the main glacial event (Hollingworth, I93 I, p. 35I), and around Loch Lomond near Glasgow a similar situation can be demonstrated statistically. In these cases the smaller drumlins are formed of bed material with a higher silt and clay content than the adjacent drumlins formed during the preceding glacial event. As the active ice thickness during the re-advance was less than that during the preceding glacial event, it seems reasonable to suggest that the different size populations in these cases represent equilibrium bed forms related to two different glacier stress/bed material resistance levels.

On the basis of this discussion, it is suggested that the assemblages of megadrumlins and drumlins in the area around Brough and Glasgow reflect progressively diminishing glacial energy regimes associated with active back-wasting glaciers. Similarly, the development of only a single bed-form population reflects a relatively constant glacial energy condition which persisted long enough for the whole glacier-bed topography to be adjusted to a particular energy regime. In order that this single population was not in turn modified, this condition must have been followed by relatively rapid wastage. Such conditions appear to have existed around Loch Lomond during the Loch Lomond re-advance, and in the Shap, Ravenstonedale and Kirkby Stephen areas of eastern Cumbria during the main Devensian glaciation. In both areas these interpretations are independently supported by associated glacigenic sediments and glaciofluvial landforms. The absence of fluted moraine from the areas used in this study should not be taken simply as evidence of a terminated hierarchy. It is likely that small features have been destroyed by periglacially induced mass wastage, such as that which occurred during Younger Dryas time (Sissons, 1974).

\section{Acknowledgements}

The authors wish to thank Professor J. R. L. Allen and John Boardman for their critical appraisal of the manuscript. Much of the field work was undertaken with the aid of grants from the Natural Environment Research Council (J.R.) and from the Central Research Fund of the University of London (J.M.L.).

MS. received I 8 January 1977

\section{REFERENCES}

Allen, J. R. L. 1968. The nature and origin of bed-form hierarchies. Sedimentology, Vol. 10, No. 3 , p. 16 I-82. Chorley, R. J. 1959. The shape of drumlins. Journal of Glaciology, Vol. 3, No. 25, p. 339-44.

Clifton, H. E., and others. $197 \mathrm{I}$. Depositional structures and processes in the non-barred high-energy nearshore,

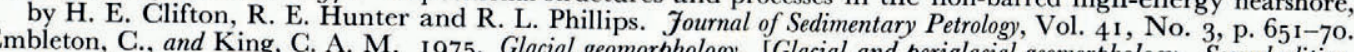
Vol. 1.] London, Edward Arnold.

Fairchild, H. L. 1929. New York drumlins. Proceedings of the Rochester Academy of Science, Vol. 3, p. 1-37.

Hollingworth, S. E. I931. The glaciation of western Edenside and adjoining areas and the drumlins of Edenside and the Solway basin. Quarterly Fournal of the Geological Society of London, Vol. 87, Pt. 2, p. 281-359. 
Hoppe, G., and Schytt, V. 1953. Some observations on fluted moraine surfaces. Geografiska Annaler, Årg. 35,

Ht. 2, p. 105-15.
Leopold, L. B., and others. 1964. Fluvial processes in geomorphology, by L. B. Leopold, M. G. Wolman and J. P. Miller.

San Francisco, W. H. Freeman.
Linton, D. L. 1962. Glacial erosion on soft-rock outcrops in central Scotland. Biuletyn Peryglacjalny, Nr. 11 ,

p. 247-57.
Rose, J., and Letzer, J. M. 1975. Drumlin measurements: a test of the reliability of data derived from $1: 25,000$ scale topographic maps. Geological Magazine, Vol. I 12, No. 4, p. 361-71.

Simons, D. B., and others. 1965. Sedimentary structures generated by flow in alluvial channels, by D. B. Simons, E. V. Richardson and G. F. Nordin, Jr. Society of Economic Palaeontologists and Mineralogists. Special Publication

No. 12, p. $34^{-52}$.
Sissons, J. B. 1974. The Quaternary of Scotland: a review. Scottish Fournal of Geology, Vol. ro, No. 4 , p. $311-37$. Smalley, I. J., and Unwin, D. J. 1968. The formation and shape of drumlins and their distribution and orientation in drumlin fields. Fournal of Glaciology, Vol. 7, No. 51, p. 377-90.

Trenhaile, A. S. 1971. Drumlins: their distribution, orientation and morphology. Canadian Geographer, Vol. 15,

[No.] 2, p. 1 $13^{-26}$.
Wilson, I. G. 197 I. Desert sandflow basins and a model for the development of ergs. Geographical Fournal, Vol. I37, Pt. 2, p. 180-99. 